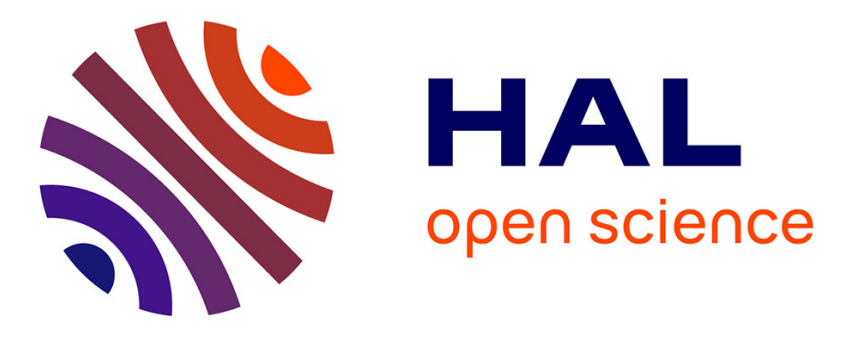

\title{
Ecotoxicological and human health risk in a petrochemical district of southern Italy
}

Antonella Ausili, Massimo Gabellini, Giuliano Cammarata, Daniele Fattorini, Maura Benedetti, Barbara Pisanelli, Stefania Gorbi, Francesco Regoli

\section{To cite this version:}

Antonella Ausili, Massimo Gabellini, Giuliano Cammarata, Daniele Fattorini, Maura Benedetti, et al. Ecotoxicological and human health risk in a petrochemical district of southern Italy. Marine Environmental Research, 2008, 66 (1), pp.215. 10.1016/j.marenvres.2008.02.062 . hal-00501957

\section{HAL Id: hal-00501957 https://hal.science/hal-00501957}

Submitted on 13 Jul 2010

HAL is a multi-disciplinary open access archive for the deposit and dissemination of scientific research documents, whether they are published or not. The documents may come from teaching and research institutions in France or abroad, or from public or private research centers.
L'archive ouverte pluridisciplinaire HAL, est destinée au dépôt et à la diffusion de documents scientifiques de niveau recherche, publiés ou non, émanant des établissements d'enseignement et de recherche français ou étrangers, des laboratoires publics ou privés. 


\section{Accepted Manuscript}

Ecotoxicological and human health risk in a petrochemical district of southern Italy

Antonella Ausili, Massimo Gabellini, Giuliano Cammarata, Daniele Fattorini, Maura Benedetti, Barbara Pisanelli, Stefania Gorbi, Francesco Regoli

PII:

S0141-1136(08)00092-5

DOI: 10.1016/j.marenvres.2008.02.062

Reference: MERE 3238

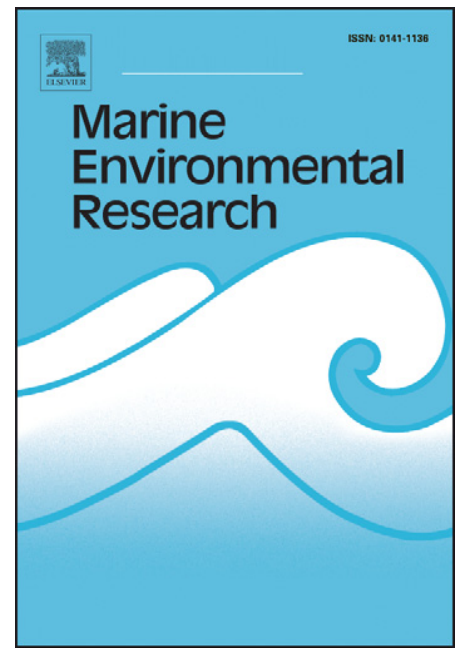

To appear in:

Marine Environmental Research

Please cite this article as: Ausili, A., Gabellini, M., Cammarata, G., Fattorini, D., Benedetti, M., Pisanelli, B., Gorbi, S., Regoli, F., Ecotoxicological and human health risk in a petrochemical district of southern Italy, Marine Environmental Research (2008), doi: 10.1016/j.marenvres.2008.02.062

This is a PDF file of an unedited manuscript that has been accepted for publication. As a service to our customers we are providing this early version of the manuscript. The manuscript will undergo copyediting, typesetting, and review of the resulting proof before it is published in its final form. Please note that during the production process errors may be discovered which could affect the content, and all legal disclaimers that apply to the journal pertain. 


\title{
Ecotoxicological and human health risk in a petrochemical district of southern Italy
}

\author{
Antonella Ausili ${ }^{a}$, Massimo Gabellini ${ }^{\text {b }}$, Giuliano Cammarata ${ }^{c}$, Daniele \\ Fattorini $^{\text {a }}$, Maura Benedetti ${ }^{\text {a }}$, Barbara Pisanelli ${ }^{\text {a }}$, Stefania Gorbi ${ }^{\text {a }}$, Francesco \\ Regoli $^{\text {a,* }}$ \\ ${ }^{a}$ Istituto di Biologia e Genetica, Università Politecnica delle Marche, Ancona, Italy. \\ ${ }^{b}$ ICRAM, Istituto Centrale per la Ricerca Scientifica e Tecnologica Applicata al Mare, Roma, Italy. \\ ${ }^{c}$ Dipartimento di Ingegneria Industriale e Meccanica, Università di Catania, Catania, Italy.
}

\begin{abstract}
An ecotoxicological investigation has been carried in the petrochemical district of Priolo (Sicily, Italy), one of the largest in Europe. Results indicated a severe mercury contamination in sediments sampled near a chloro-alkali plant. A clear bioavailability of this element was demonstrated in mussels Mytilus galloprovincialis (both native and translocated) and the benthic fish Mullus barbatus, which also exhibited marked genotoxic damages. The elevated mercury concentrations in marine organisms are a serious concern for human health; according to the national average fish consumption, the provisional tolerable weekly intake (PTWI) of $\mathrm{Hg}$ would be easily exceeded by at least 4 to 12 fold. Such toxicological risk is of particular importance for pregnant women, being possibly involved in the elevated frequency of neonatal malformations.
\end{abstract}




\section{ACCEPTED MANUSCRIPT}

Keywords: Mercury; Bioavailability; Mytilus galloprovincialis; Mullus barbatus; Genotoxicity; Human health risk; Priolo petrochemical site

*Corresponding author: Via Ranieri (Montedago) 65, 60131-Ancona, Italy. Tel +390712204613; fax +390712204609

E-mail address: f.regoli@univpm.it (F. Regoli)

Since the early 1950s, the industrial area of Priolo (Sicily, Italy) became one of the largest and most complex petrochemical sites in Europe, containing several oil refineries, chemical plants, mineral deposits, a military base and many other industrial installations. Nowadays, it is a high environmental risk area due to the uncontrolled chemical discharges that occurred before the Water Pollution Control law (Merli law, 1978) and frequent industrial accidents.

The aim of this study was to characterize the main chemical pollutants in the sediments, and to assess their bioavailability and toxicological effects in classical bioindicator species: the mussel (Mytilus galloprovincialis) and the red mullet (Mullus barbatus) were selected to compare the potential exposure respectively through the water column or sediments.

Results obtained were discussed in terms of potential risk for human health from seafood consumption of particular relevance for this area where the incidence of neonatal malformations is more than 3-fold higher than the national average (Bianchi et al., 2004).

Sediments and organisms were collected from various sites in the petrochemical area between Augusta and Priolo (Fig. 1A); mussels were also caged for 4 weeks close to an industrial wharf. Chemical analyses included trace metals, polycyclic aromatic hydrocarbons, polychlorinated biphenyls and hexachlorobenzene; however only results concerning mercury $(\mathrm{Hg})$ will be presented here since this element appeared as the most relevant pollutant. 


\section{ACCEPTED MANUSCRIPT}

Close to a chloro-alkali plant, the $\mathrm{Hg}$ concentrations in sediment cores ranged between 25 and $90 \mu \mathrm{g} \cdot \mathrm{g}^{-1}$ dry weight (d.w.) in the superficial layer and between 50 to $350 \mu \mathrm{g} \cdot \mathrm{g}^{-1}$ in the $28-30 \mathrm{~cm}$ layer: these results indicate that a massive contamination occurred in the 1970s, and that $\mathrm{Hg}$ discharge is still ongoing in this area, which can be certainly defined as the most $\mathrm{Hg}$ polluted site in the Mediterranean. The bioavailability of mercury to marine organisms was clearly demonstrated by the analyses on both native and caged mussels. Wild specimens collected in various sites around the plant exhibited concentrations from 2 up to $5 \mu \mathrm{g} \cdot \mathrm{g}^{-1}$, approximately 60 -fold higher than those measured in control organisms (Fig. 1B). Bioaccumulation of $\mathrm{Hg}$ was also very rapid in caged mussels which, after 4 weeks, exhibited comparable values to those of native organisms. Considering that $\mathrm{Hg}$ concentrations rapidly decreased in the water column of polluted sites after the closure of discharges (Francesconi et al., 1997; Sager, 2002), our results further highlight the presence of inputs still releasing this element in the marine environment.

Bioavailability of mercury to marine organisms was even more evident in the benthic fish $M$. barbatus (Fig. 1C). Concentrations in muscle tissues were around $10 \mu \mathrm{g} \cdot \mathrm{g}^{-1}$, while the liver exhibited similar or higher values, up to $30 \mu \mathrm{g} \cdot \mathrm{g}^{-1}$, in organisms sampled in more coastal sites close to the industrial wharf. Levels measured in control specimens were lower than $1 \mu \mathrm{g} \cdot \mathrm{g}^{-1}$ in both the tissues. Despite relatively high mercury concentrations occurring naturally in muscle tissues of Mediterranean fish, due to a geochemical anomaly and biomagnification (Bargagli, 1999), the exceptionally high values measured in this low trophic-level species and the remarkable accumulation in liver indicate that exposure through contaminated sediments has a much greater significance as compared to long term transfer via food-web.

Besides chemical accumulation, there was also evidence of toxicological effects of mercury in both mussels and red mullets. The incidence of micronuclei $(\mathrm{MN})$, respectively in the haemocytes and gills, revealed a frequency up to $11 \%$ in molluscs and $9 \%$ in fish (Fig. 2). Similar values have never been previously reported, especially for mussels (Bolognesi et al., 2006), and clearly demonstrate a marked biological reactivity of environmental mercury. 


\section{ACCEPTED MANUSCRIPT}

From obtained results, the risk for human health from seafood consumption appears to be a real issue. International Agencies indicate provisional tolerable weekly intake (PTWI) of $\mathrm{Hg}$, ranging from $0.7 \mu \mathrm{g} / \mathrm{Kg}$ body weight (b.w.) (USEPA, 2001) to $1.6 \mu \mathrm{g} / \mathrm{Kg}$ b.w. (FAO/WHO, 2003). These limits represent safe values which can be accumulated by the human population over lifetime. However, different considerations are recommended for pregnant women, nursing mothers and young children; due to the toxic effects of $\mathrm{Hg}$ on the developing nervous system, these categories should avoid the consumption of fish species which normally have a higher mercury content (NRC, 2000; USEPA/ FDA 2004). In this study, the median Hg values for fish muscle (converted to wet weight) were $1.43 \mu \mathrm{g} \cdot \mathrm{g}^{-1} \mathrm{w} . \mathrm{w}$. when considering all the sites, or $2.06 \mu \mathrm{g} \cdot \mathrm{g}^{-1} \mathrm{~W} \cdot \mathrm{w}$. for only the most impacted. Consequently, a $60 \mathrm{Kg}$ women would thus assume a weekly $\mathrm{Hg}$ PTI (0.7-1.6 $\mu \mathrm{g} / \mathrm{Kg}$ b.w.) from 30-67 $\mathrm{g}$ or $20-46 \mathrm{~g}$ of fish caught in different sites of the industrial area of Priolo. Since the national average of fish consumption for the Italian population is estimated to be $33.9 \mathrm{~g}$ per capita per day (approximately $240 \mathrm{~g}$ per week, Turrini and Sermoneta, 2004), a $60 \mathrm{Kg}$ women consuming organisms from Priolo would exceed the Hg PTWI by at least 4 to12-fold. In addition, criteria developed to protect human health from mercury in fish products, indicate that calculations for pregnant women should consider a fish consumption 3-fold higher than the national average (USEPA, 2001). The application of this cautionary procedure would further increase the exceeding of recommended safe limits for the area of Priolo, confirming consumption of seafood as a serious concern for pregnant women. The hypothesis of human health risk is supported by the frequency of neonatal malformations, which in 2001 was $5.5 \%$ for the area of Priolo-Augusta, versus a national average of $1.5 \%$ and a risk value indicated by WHO at 2\% (Bianchi et al., 2004).

The overall results demonstrated a severe mercury contamination in the area investigated, resulting in a marked bioavailability for marine species and the real possibility for pregnant women to exceed the maximum safe limits for $\mathrm{Hg}$ uptake from seafood. 


\section{ACCEPTED MANUSCRIPT}

\section{References}

Bargagli, R. (1999). In: Encyclopedia of Environmental Sciences, Alexander D.E. and Fairbridge

R.W. (eds.). Kluwer Academic Publishers Dordrecht,The Netherlands, pp. 402-405.

Bianchi, F., Bianca, S., Linzalone, N., and Madeddu, A. (2004). Epidemiologia e Prevenzione, 28, 87-93.

Bolognesi, C., Perrone, E., Roggieri, P., and Sciutto, A. (2006). Marine Environmental Research, $62,287-291$.

FAO/WHO (2003). JECFA/61/SC, ftp://ftp.fao.org/es/esn/jecfa/jecfa61sc.pdf.

Francesconi, K.A., Lenanton, R.C.J., Caputi, N., and Jones, S. (1997). Marine Environmental Research, 43, 27-40.

NRC, National Research Council (2000). Toxicological Effects of Methylmercury. National Academy Press, Washington DC, USA.

Sager D. R. (2002). Marine Pollution Bulletin, 44, 807-815.

Turrini A., and Sermoneta C. (2004). Rapporti ISTISAN 05/24, http://www.iss.it/binary/publ/ publi/05-24.1129716985.pdf, pp. 17-30.

U.S. Environmental Protection Agency (2001). Water Quality Criterion for the Protection of Human Health: Methylmercury Chapter 4: Risk Assessment for Methylmercury. Office of Science and Technology, Office of Water, EPA-823-R-01-001.

U.S. Environmental Protection Agency \& Food and Drug Administration (2004). Joint Federal Advisory for Mercury in Fish, http://www.epa.gov/waterscience/fishadvice/advice.html 


\section{Figure captions}

Fig. 1. (A) Sampling locations in the industrial area of Priolo for native mussels (M), transplanted mussels (TR) and fish (F). (B) and (C) Mercury concentrations $\left(\mu \mathrm{g} \bullet \mathrm{g}^{-1}\right.$ d.w.) in whole tissues of $M$. galloprovincialis and in liver or muscle of $M$. barbatus. Values are reported as means \pm standard deviations $(n=10)$. For mussels different letters indicate significant differences between sites (one way analysis of variance, ANOVA, and post-hoc comparison); for red mullets small letters and capital letters indicate differences between sites for liver and muscle, while asterisks indicate differences between tissues (two ways ANOVA, and post-hoc comparison, $* \mathrm{p}<0.05 ; * * \mathrm{p}<0.0001$ ).

Fig. 2. Frequency (\%o) of micronuclei (MN) in haemocytes of M. galloprovincialis (A) and gills of M. barbatus (B). Values are reported as means \pm standard deviations $(\mathrm{n}=10)$; different letters indicate significant differences between organism from various sampling sites (one way ANOVA and post-hoc comparison). 


\section{ACCEPTED MANUSCRIPT}

Figure 1.
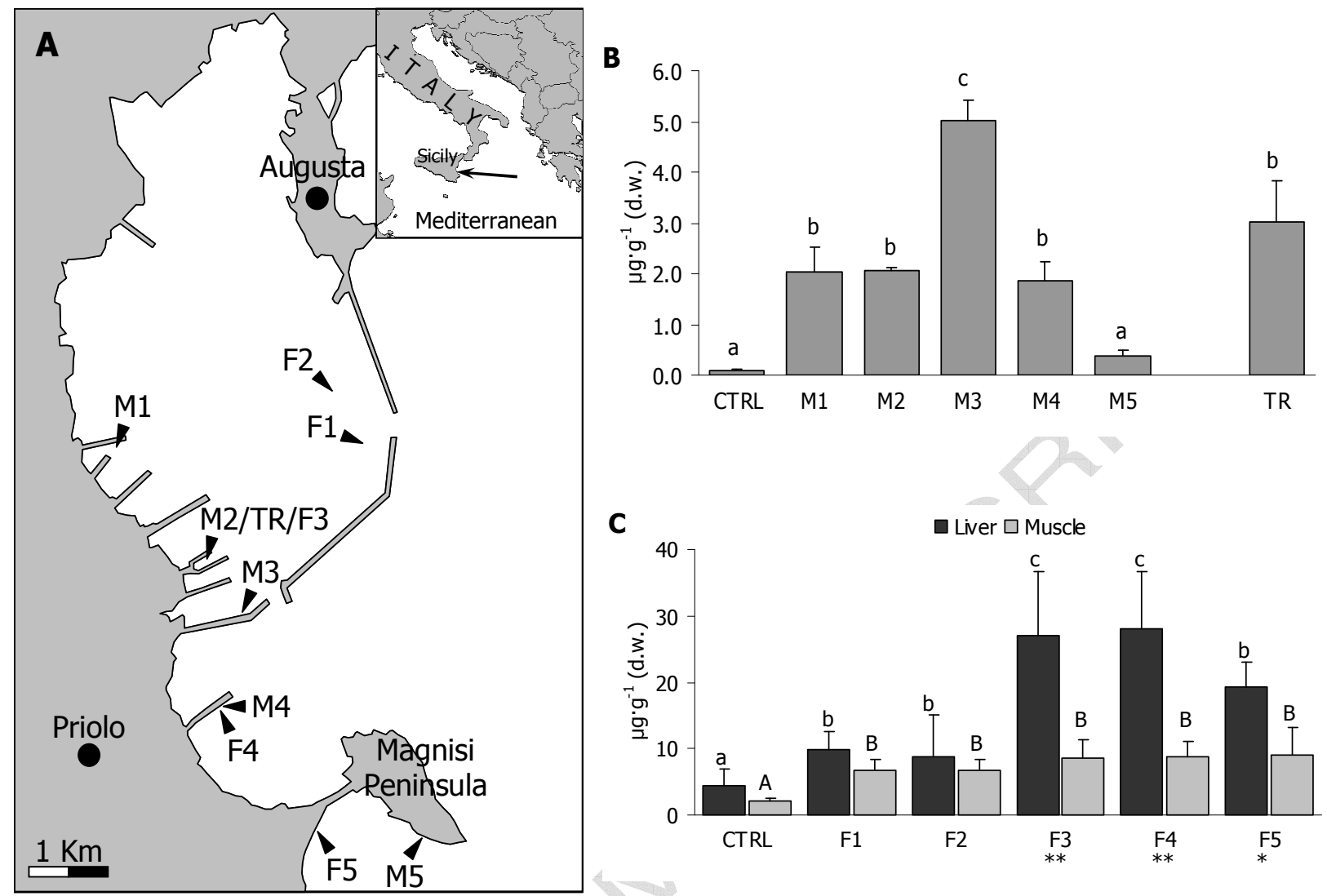
Figure 2.
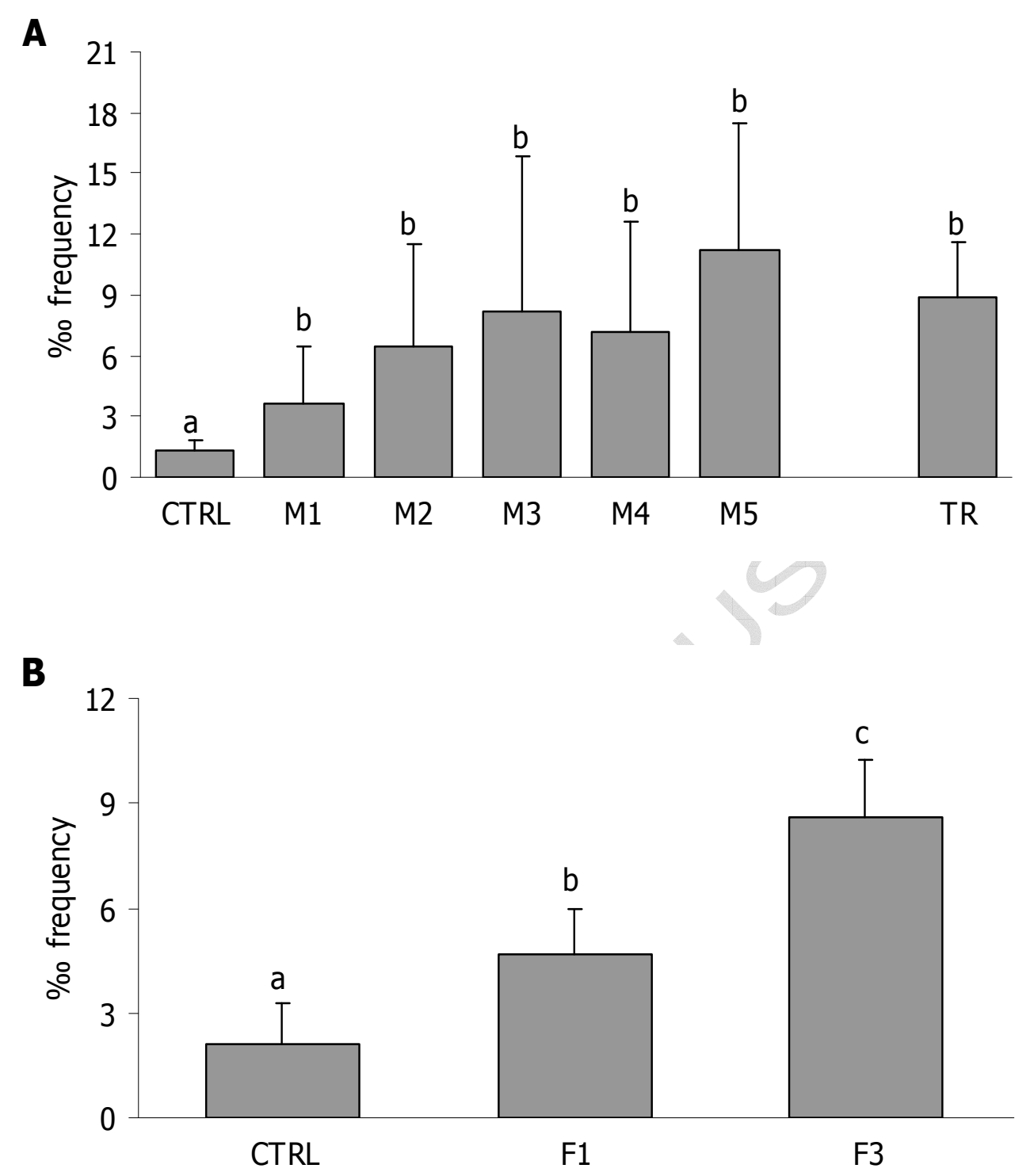